\title{
Security Implications of Neutrality: Switzerland in the Partnership for Peace Framework
}

\author{
Marjorie Andrey *
}

\begin{abstract}
Isolation in the twenty-first century is not only a crime, but a political blunder. But the desire for active participation in the life of an international system must be tempered by an awareness of what is possible. A small state, more than any other, must have either a policy in line with its means, or the means to uphold its policy.
\end{abstract}

Jacques Freymond, $1971^{1}$

\section{Introduction}

This article presents the security policy implications of neutrality for Switzerland in the terms of international promotion of peace and crisis management. It focuses particularly on the country's engagement within NATO's Partnership for Peace (PfP) framework, considering the achievements and the challenges of Switzerland's singular choices in foreign and security policy. We will see that permanent neutrality and domestic factors in Switzerland have a huge impact on the nation's involvement in the Euro-Atlantic partnership and in the construction of European security. ${ }^{2}$ It will also reflect the differences between civilian and military contributions to international crisis management. Finally, the essay will consider the prospects for Swiss international engagement, and propose some conditions for a relevant Swiss foreign and security policy.

\section{Neutral Switzerland in the PfP}

\section{The Concept of Neutrality}

To understand the application of neutrality, it is important to briefly define the concept. Neutrality implies the military non-participation of a state in an armed conflict between states. It can be decided on an ad hoc basis, with regard to a particular conflict, or it can be decided in a general manner and applied permanently, as is the case today in Switzerland. It is important to distinguish between two notions: neutrality law and neutrality policy. Neutrality law refers to the set of rules related to international public law that neutral and belligerent states are bound by in times of international armed con-

\footnotetext{
Ms Andrey, a Swiss citizen, is a graduate of the Geneva Centre for Security Policy's 24th International Training Course and the parallel 2009-2010 MAS Programme at the University of Geneva.

1 Laurent Götschel, ed., Small States Inside and Outside the European Union: Interests and Policies (Boston, MA: Kluwer Academic Publishers, 1998), 42.

2 The Euro-Atlantic Partnership encompasses the concepts of the PfP and the Euro-Atlantic Partnership Council (EAPC).
} 
flict. International customary law and the 1907 Hague Conventions are the sources of international neutrality law. ${ }^{3}$ This body of law applies to armed conflicts between states, and not to internal conflicts. Nor is it applicable in cases of a decision made by the UN Security Council under the framework of Chapter VII of the UN Charter. ${ }^{4}$

Neutrality policy, on the other hand, consists of all the measures a state can take on its own initiative (besides legal obligations) to ensure the efficiency and credibility of a decision regarding neutrality. In these conditions, the neutral state has total freedom to use neutrality as a flexible instrument to manage its national interests in the context of its foreign and security policy.

It is worth understanding the logic and sources of Switzerland's atypical path in directing its foreign and security policy. After considering its neutrality, we will examine its impact on the Swiss current policy and its limits. Does this make the Swiss position unique? What are the security policy implications of Swiss neutrality, more particularly in the context of NATO's PfP? We will then discuss some potential directions Swiss security policy-makers may take in the future.

\section{Origin and Evolution of Swiss Neutrality}

The traditional origin story of Swiss neutrality holds that the Swiss Confederates applied de facto neutrality after their defeat at the Battle of Marignano in 1515. The official policy goes back to the 1815 Congress of Vienna, when Swiss neutrality was formally established and recognized by the European powers. Switzerland has since applied deliberate, permanent, and armed neutrality. Permanent neutrality does not mean that this status must be maintained forever. However, neutrality is inscribed in the Swiss Federal Constitution; Articles 173 and 185 stipulate that the Federal Assembly and the Federal Council must take the necessary measures to preserve the external security, independence, and neutrality of Switzerland. ${ }^{5}$ It is also worth mentioning here that, according to the Swiss system of democracy, any amendment of the constitution must be accepted by obligatory referendum. Moreover, Switzerland's largely positive historical experience of remaining neutral in European conflicts has fully integrated neutrality into the Swiss national identity, for both external and domestic reasons of cohesion. However, neutrality has never been mentioned as being among primary goals of the state, nor has it been discussed as one of the key principles of Swiss for-

3 Convention V (Rights and Duties of Neutral Powers and Persons in Case of War on Land) and Convention XIII (Rights and Duties of Neutral Powers in Naval War), in The Hague Conventions and Declarations (The Hague: 18 October 1907); available at http://avalon.law.yale.edu/subject_menus/lawwar.asp.

4 United Nations, UN Charter, Chapter VII (Action with Respect to Threats to the Peace, Breaches of the Peace, and Acts of Aggression) (New York: United Nations, 26 June 1945); available at www.un.org/en/documents/charter/chapter7.shtml.

5 Die Bundesbehörden der Schweizerischen Eidgenossenschaft, Bundesverfassung der Schweizerischen Eidgenossenschaft, SR-Nummer 101 (Bern: 18 April 1998), Articles 173.a and $185.1 ;$ available at www.admin.ch/ch/f/rs/c101.html. 
eign policy. ${ }^{6}$ It has always been understood as an instrument of the foreign and security policy of the country, which has seemed so far to be the approach best suited to protecting the state's interests.

Indeed, the 1993 "Report on Neutrality" clearly acknowledges the changing nature of the international environment since the collapse of the Soviet Union, and the impact on Swiss neutrality policy:

The defense of our country's interests in foreign policy calls for an active position of global solidarity. The instrument of neutrality has since lost a part of its efficiency and forcefulness. ... Openness [includes] participation [in] measures against the new forms of threats and to the setting-up of solid security structures. Continuity is refusing to precipitately abandon security mechanisms [that] have given complete satisfaction. Such a strategy of solidarity and participation combined with our own efforts of defense in the limits of our permanent neutrality meet [the] legitimate security needs of a small state. It reflects at the same time our [commitment to] self-determination and our understanding of the fact that our destiny is inextricably linked with the European continent. ${ }^{7}$

Policy changes have since been visible in different areas, such as terrorism or sanctions policy. Switzerland decided to adjust its approach to sanctions along with UN and EU decisions, as was the case in the 1990 sanctions against Iraq. In that same context, in 1996 Switzerland joined NATO's PfP, which is recognized as an important part of the European security architecture.

\section{Switzerland and the PfP}

The PfP is not an organization but an instrument, the main advantages of which are the principles of voluntary participation and self-differentiation. It therefore allows cooperation based on the distinct needs and interests of nations like Switzerland. This flexibility provides Swiss authorities with an adequate civilian and military tool for participating in the European security system and a useful role to play in the promotion of peace - on that in both cases is still compatible with neutrality. Within the Individual Partnership Program (IPP) framework, Bern is active in developing initiatives in priority domains for its foreign and security policy. ${ }^{8}$ Among other goals, the PfP offers an ideal platform for promoting international humanitarian law, a key objective of Swiss foreign policy. Swiss expertise has also been involved in Security Sector Reform

6 L'Essentiel sur la neutralité suisse (Bern: DFAE); available at www.eda.admin.ch/etc/ medialib/downloads/edazen/topics/intla/cintla.Par.0008.File.tmp/PDF_Haupttext_Neutralitaet_ fr.pdf.

7 Translated by the author, from Département fédéral des affaires étrangères, Rapport sur la neutralité publié en annexe du Rapport sur la politique extérieure de la Suisse dans les années 90 (Bern: DFAE, 29 November 1993), 11; available at www.eda.admin.ch/etc/ medialib/downloads/edazen/doc/publi.Par.0006.File.tmp/Rapport\%20sur\%201a\%20neutralit e\%201993.pdf.

8 Directorate for Security Policy, Individual Partnership Program between Switzerland and NATO for 2010, NATO/EAPC/PfP Unclassified Switzerland only, Annex 1 (Bern: DSP, 19 November 2009), 2; available at www.pfp.admin.ch/internet/partnership_for_peace/fr/home/ bibliothek.html. 
(SSR) projects, in line with the nation's interest in supporting the democratization and democratic control of armed forces. Beside this, the defense sector is committed to maintaining its efforts toward achieving interoperability and building capacities in international crisis management.

The PfP's approach to military cooperation includes four pillars. The first is the Planning and Review Process (PARP), which provides partner states with the requirements necessary to achieve interoperability and capability, helps countries to improve their own defense capacities, and guides them in preparing their contributions to NATO's crisis response capability. Switzerland started this process in 1999, and has since achieved appreciable results in terms of standardization with NATO processes, definitions, and technology. The current twenty-four Partnership Goals form the basis for assisting Partner countries in planning their targets. Should Switzerland decide to increase its military contributions to the Alliance, the PfP Planning and Review Process would be further developed in that direction. The second pillar includes training courses offered by NATO members or partners under the Euro-Atlantic Partnership Work Plan (EAPWP) framework. Each year the Federal Council reviews and decides on the training activities that Switzerland will offer to staff from allied and partner states. The 2010 IPP offers twenty-one training activities, run in collaboration with the Federal Department of Defense, Civil Protection, and Sport, the Federal Department of Foreign Affairs, and the Swiss-based centers ${ }^{9}$ that are part of Switzerland's contributions to the PfP. ${ }^{10}$ The PARP and EAPWP are complemented by the third pillar - the Operational Capabilities Concept (OCC) - as the "NATO commanders need to know what forces are available and how capable they are." ${ }^{11}$ This completes the PARP by assessing the real interoperability and readiness of partner states' troops for potential peace support operations (PSOs). While it conducts its own assessments, Switzerland's contributions are also regularly evaluated by NATO officials. Military exercises constitute the fourth pillar. Swiss participation in them is decided on a yearly basis, according to the needs of the Swiss Armed Forces.

The level of civilian contributions to PfP is remarkable. Switzerland actively supports SSR projects in Eastern and South Eastern Europe, South Caucasus, and Central Asia. This is achieved in line with the Partnership Action Plan for Defense Institution Building (PAP-DIB), with the aim to help these countries achieve democratic control of their armed forces. Switzerland complements this aid by financing various trust funds, ${ }^{12}$ including those dedicated to the fight against corruption in the defense sector, reduction of stockpiles of arms and munitions, and the elimination of UXOs (unex-

9 ISN (International Relations and Security Network), GCSP (Geneva Centre for Security Policy), DCAF (Geneva Centre for the Democratic Control of Arms), GICHD (Geneva International Centre for Humanitarian Demining).

10 Directorate for Security Policy, 5.

11 Susan Pond, "Understanding the PfP Tool Kit," NATO Review (Spring 2004); available at www.nato.int/docu/review/2004/issue1/english/art2.html.

12 NATO established this mechanism in 2000 , initially to support partner countries in their program of elimination of anti-personnel landmines. 
ploded ordnance).$^{13}$ Beside these contributions, Swiss departments organize various seminars on the theme of international humanitarian law. Jointly with Great Britain, in December 2009 Switzerland organized an EAPC workshop on private military and security companies (PMSCs). The workshop was based on the Montreux Document, prepared in 2006 by the Swiss government and the International Committee of the Red Cross (ICRC), to establish some legal ground rules for the use of PMSCs in armed conflicts. These activities represent not only an opportune mechanism of practical civilian and military cooperation, but are also an essential part of Swiss foreign policy within the EAPC.

\section{Switzerland and the EAPC}

Besides the OSCE and the Council of Europe, the EAPC represents the only genuinely effective institutionalized forum available to Switzerland within the European security architecture. The main challenge today is to maintain its relevance not only for the Partners, but also for NATO itself, which is now focusing its attention on current operations in Afghanistan and is still in search of a new global strategy that will enable the Alliance to apprehend present and future security challenges. In this context it is difficult for small countries like Switzerland to capitalize on the advantages provided by the EAP. Very few ministerial meetings take place with an agenda covering topics other than military operations (the last one was the Bucharest Summit, in 2008). Moreover, and "too often, partner countries tend to be assessed mainly according to their purely military contribution to operations." ${ }^{14}$ The principles of flexibility and selfdifferentiation are also being called into question with the suggestion of some allied nations of standardizing all of NATO's partnerships. This intention is rather paradoxical, given the fact that the Alliance regularly acknowledges the importance of its partnerships. It would cut off a successful partnership such as the PfP from its very substance. Instead, the sensible and pragmatic course would be to adopt a global approach to security needs, and to value the various contributions of partner states such as the Western Five, which are net security producers. This must be done by respecting the specific qualities of each partnership, because this differentiation among the partnerships represents precisely the motivation for small and neutral countries like Switzerland to participate in NATO's activities and thus contribute to European security. The unofficial policy document elaborated by Austria, Ireland, and Switzerland in view of the new Strategic Concept goes in that direction, and recommends further improve-

13 Eidgenössisches Departement für Verteidigung, Bevölkerungsschutz, und Sport, Generalsekretariat Sicherheitspolitik SIPOL, Jahresbericht 2009 des Bundesrates über die Teilnahme der Schweiz am Euro-Atlantischen Partnerschaftsrat und an der Partnerschaft für den Frieden, Entwurf (Bern: VBS-EDA, 2010), 7; available at www.pfp.admin.ch/ internet/partnership_for_peace/de/home/bibliothek.html.

14 Jean-Jacques de Dardel, "Whither the Euro-Atlantic Partnership? Partnership and NATO's New Strategic Concept," GCSP Geneva Papers 10 (Geneva: Geneva Centre for Security Policy, 2009), 24; available at www.gcsp.ch/Euro-Atlantic-Security/Recent-Publications/ Whither-the-Euro-Atlantic-Partnership-Partnership-and-NATO-s-New-Strategic-Concept. 
ments in the wake of the modifications implemented at the Bucharest Summit. These countries highlight the effectiveness of flexibility and self-differentiation. Among various recommendations, they call for more recognition of civilian contributions and deepened consultation, particularly with respect to decision making. ${ }^{15}$ A major challenge facing PfP states today is avoiding being marginalized within NATO's partnerships network. But in this game, unlike other Western Five states, Switzerland cannot really put forward the argument of its effective military contributions, since at present Switzerland's military contributions to NATO's operations are limited to a 220-man infantry company (see Figure 1). Austria provides double this amount of troops, and Sweden and Finland provide three times more troops, including their contributions to ISAF.

\section{Challenges to Euro-Atlantic Military Participation}

Swiss military participation in NATO peace support operations is not hampered by legal constraints. Under the requirements of the Federal Constitution, the Swiss Confederation is committed to preserving a just and peaceful international order. ${ }^{16}$ The 1995 Federal Law on the Swiss Army also contains provisions that bolster this obligation; Articles 66, 66a, and 66b give the conditions for military involvement in peace support efforts, which must be based on a UN or OSCE mandate. An amendment passed by referendum in 2001 allows the Federal Council to deploy armed troops, after consultation with the Parliament. Similar consultation is required if the engagement involves more than one hundred troops or lasts more than three months. Use of arms is intended for self-defense only. Switzerland is also the only country to legally prohibit its troops from participation in combat. ${ }^{17}$ Unlike the legal stipulations of the Austrian model, the Swiss system does not require professional officers to participate in external missions, even though such a requirement would provide officers with the opportunity to gain concrete experience in the field of crisis management. Beside the legal considerations, it is also necessary to look at the actual capacities and the potential contributions of the Swiss Armed Forces in these external operations.

Although its strengths have been considerably transformed, the Swiss Army has oriented its strategy towards international cooperation in a much more limited way than Austria, Ireland, Sweden, and Finland, which have systematically aligned their policy with European security objectives and international crisis management capacities. In the field, the Swiss Armed Forces must also choose their missions according to their

15 Government of Austria, Ireland and Switzerland, For a Euro-Atlantic Partnership (EAP) Looking to the Future: Proposals for NATO's New Strategic Concept, unofficial policy document submitted by Austria, Ireland and Switzerland (December 2009); available at www.decentralisation2010.ch/eda/fr/home/topics/intorg/pfp/misnat/nastra.html.

16 Die Bundesbehörden der Schweizerischen Eidgenossenschaft, Bundesverfassung der Schweizerischen Eidgenossenschaft, Article 2.4.

17 Die Bundesbehörden der Schweizerischen Eidgenossenschaft, Bundesgesetz über die Armee und die Militärverwaltung (Militärgesetz, MG), SR-Nummer 510.10 (Bern: VBS, 3 February 1995); available at www.admin.ch/ch/d/sr/510_10/index.html. 
FALL 2010

\begin{tabular}{|c|c|c|c|c|c|c|c|c|c|c|}
\hline & \multicolumn{2}{|c|}{ Austria } & \multicolumn{2}{|c|}{ Finland } & \multicolumn{2}{|c|}{ Ireland } & \multicolumn{2}{|c|}{ Sweden } & \multicolumn{2}{|c|}{ Switzerland } \\
\hline $\begin{array}{l}\text { Troops } \\
\text { engaged in } \\
\text { PSOs } \\
\text { Average } \\
2005-10\end{array}$ & \multicolumn{2}{|c|}{1221} & \multicolumn{2}{|c|}{763} & \multicolumn{2}{|c|}{704} & \multicolumn{2}{|c|}{856} & \multicolumn{2}{|c|}{268} \\
\hline $\begin{array}{l}\text { Troops } \\
\text { engaged in } \\
\text { PSOs } \\
2010\end{array}$ & \multicolumn{2}{|c|}{1090} & \multicolumn{2}{|c|}{675} & \multicolumn{2}{|c|}{752} & \multicolumn{2}{|c|}{709} & \multicolumn{2}{|c|}{254} \\
\hline $\begin{array}{l}\text { \% NATO } \\
\text { PSOs }\end{array}$ & \multirow{2}{*}{\multicolumn{2}{|c|}{$41.37 \%$}} & \multirow{2}{*}{\multicolumn{2}{|c|}{$84.44 \%$}} & \multicolumn{2}{|c|}{$31.91 \%$} & \multirow{2}{*}{\multicolumn{2}{|c|}{$95.20 \%$}} & \multicolumn{2}{|c|}{$81.49 \%$} \\
\hline 2010 & & & & & & & & & & \\
\hline $\begin{array}{l}\% N A T O \\
P S O s \\
2009\end{array}$ & \multicolumn{2}{|c|}{$49.68 \%$} & \multicolumn{2}{|c|}{$67.51 \%$} & \multicolumn{2}{|c|}{$14.05 \%$} & \multicolumn{2}{|c|}{$59.68 \%$} & \multicolumn{2}{|c|}{$81.18 \%$} \\
\hline $\begin{array}{l}\text { Main PSOs } \\
\text { Contingents } \\
(\geq 20)\end{array}$ & 2010 & $\underset{*}{\operatorname{Max}}$ & 2010 & $\underset{*}{\operatorname{Max}}$ & 2010 & $\underset{*}{\operatorname{Max}}$ & 2010 & $\underset{*}{\operatorname{Max}}$ & 2010 & $\underset{*}{\operatorname{Max}}$ \\
\hline $\begin{array}{l}\text { Afghanistan: } \\
\text { NATO ISAF }\end{array}$ & - & - & 165 & 165 & - & - & 430 & 430 & - & - \\
\hline $\begin{array}{l}\text { Kosovo: } \\
\text { NATO KFOR }\end{array}$ & 447 & 623 & 405 & 510 & 233 & 233 & 245 & 650 & 207 & 220 \\
\hline $\begin{array}{l}\text { Bosnia: } \\
\text { EUFOR } \\
\text { Althea }\end{array}$ & 96 & 291 & 4 & 200 & 43 & 57 & 0 & 77 & 25 & 27 \\
\hline $\begin{array}{l}\% \text { in the } \\
\text { Balkans } \\
2010\end{array}$ & & $1 \%$ & & $9 \%$ & & $0 \%$ & & $5 \%$ & & \\
\hline $\begin{array}{l}\% \text { in the } \\
\text { Balkans } \\
2009\end{array}$ & & $5 \%$ & & $4 \%$ & & $7 \%$ & & $6 \%$ & & \\
\hline $\begin{array}{l}\text { CAR/Chad: } \\
\text { MINURCAT } \\
2010\end{array}$ & 131 & 131 & 74 & 74 & 427 & 427 & - & - & - & - \\
\hline $\begin{array}{l}\text { Liberia: } \\
\text { UNMIL }\end{array}$ & - & - & - & - & 0 & 413 & 0 & 234 & - & - \\
\hline $\begin{array}{l}\text { Syria/Israel: } \\
\text { UNDOF }\end{array}$ & 378 & 383 & - & - & - & - & - & - & - & - \\
\hline $\begin{array}{l}\text { Lebanon: } \\
\text { UNIFIL }\end{array}$ & - & - & 0 & 205 & - & 166 & 0 & 42 & - & - \\
\hline $\begin{array}{l}\% \text { UN PSOs } \\
2010\end{array}$ & & & & $\%$ & & $\%$ & & $2 \%$ & & \\
\hline
\end{tabular}

Figure 1: Military Contributions to Peacekeeping Operations by the Western Five. 
capacities. For example, the Swiss military is capable of maintaining operations in such areas as logistics and transmission at only a very low level. Therefore, Swiss contributions can only be managed in a niche scheme. ${ }^{18}$ Given the Swiss Armed Forces' current limited capabilities, the pursuit of niche opportunities in PSOs seems to be so far the most realistic direction for the Army to pursue. This constraint would immediately appear again should Switzerland extend its participation in current operations. Complementarity with other contributors should and will certainly be considered when deciding to continue and increase Swiss support to KFOR. This factor brings about the broader question concerning the organization and missions of the Swiss Armed Forces.

As defined in the Federal Law on the Swiss Army, the main missions of the Army are the defense of the population and the territory, as well as the international promotion of peace. ${ }^{19}$ The distinction of roles between the Army and the cantonal police forces in the defense of the population is neither clear nor satisfactory. As will be discussed in the next section, military peace promotion is also very controversial among the public as well as the political class. Finally, in the new security context-an environment characterized by European stability and the globalization of security challenges - immediate geographical threats have become highly improbable. As a consequence, the defense of Swiss territory is no longer a relevant mission. This challenges the very raison d'être of the Swiss Army, which is gradually losing its credibility as an actor in Swiss security. Switzerland should take a radical shift from a Cold War security concept to a true cooperative approach to defense, which is today "conceivable only in a European framework." ${ }^{20}$ Unfortunately, the latest "Security Policy Report" of the Federal Council clarifies neither the organization of security actors nor a strategy for achieving Swiss security policy. It only reflects the divergences between governmental players on these issues. ${ }^{21}$ Ideally, such a shift should be decided at the political level, and guided only indirectly by public opinion.

\section{Swiss Politics and Public Opinion}

Compared with the spirit prevailing in the 1990s, the margin of maneuver regarding international involvement is currently much narrower for the Swiss government than is the case in other countries. This has been accentuated with the polarization of political forces in the Swiss Parliament. Not only is there no longer any sustained debate about the relevance of neutrality, but any discussion on any potential military participation in

18 This policy appeared along with the idea of an EU army: each country would provide it with contributions in areas where they possess comparative advantages (British infantry, German navy, French intervention troops, etc.).

19 Die Bundesbehörden der Schweizerischen Eidgenossenschaft, Bundesgesetz über die Armee und die Militärverwaltung (Militärgesetz, $M G$ ), Article 1.

20 Translated by the author, from Daniel Möckli, ed., "Auslandeinsätze der Armee: Stand und Optionen," CSS Analysen zur Sicherheitspolitik 67 (Zürich: CSS ETH Zürich, February 2010); available at www.ssn.ethz.ch/Aktuell/CSS-Analysen/Detail/?lng=de\&id=112179.

21 Der Schweizerische Bundesrat, Bericht des Bundesrates an die Bundesversammlung über die Sicherheit der Schweiz, Entwurf (Bern: VBS, 14 April 2010); available at www.vbs.admin.ch/ internet/vbs/de/home/documentation/bases/sicherheit.html. 


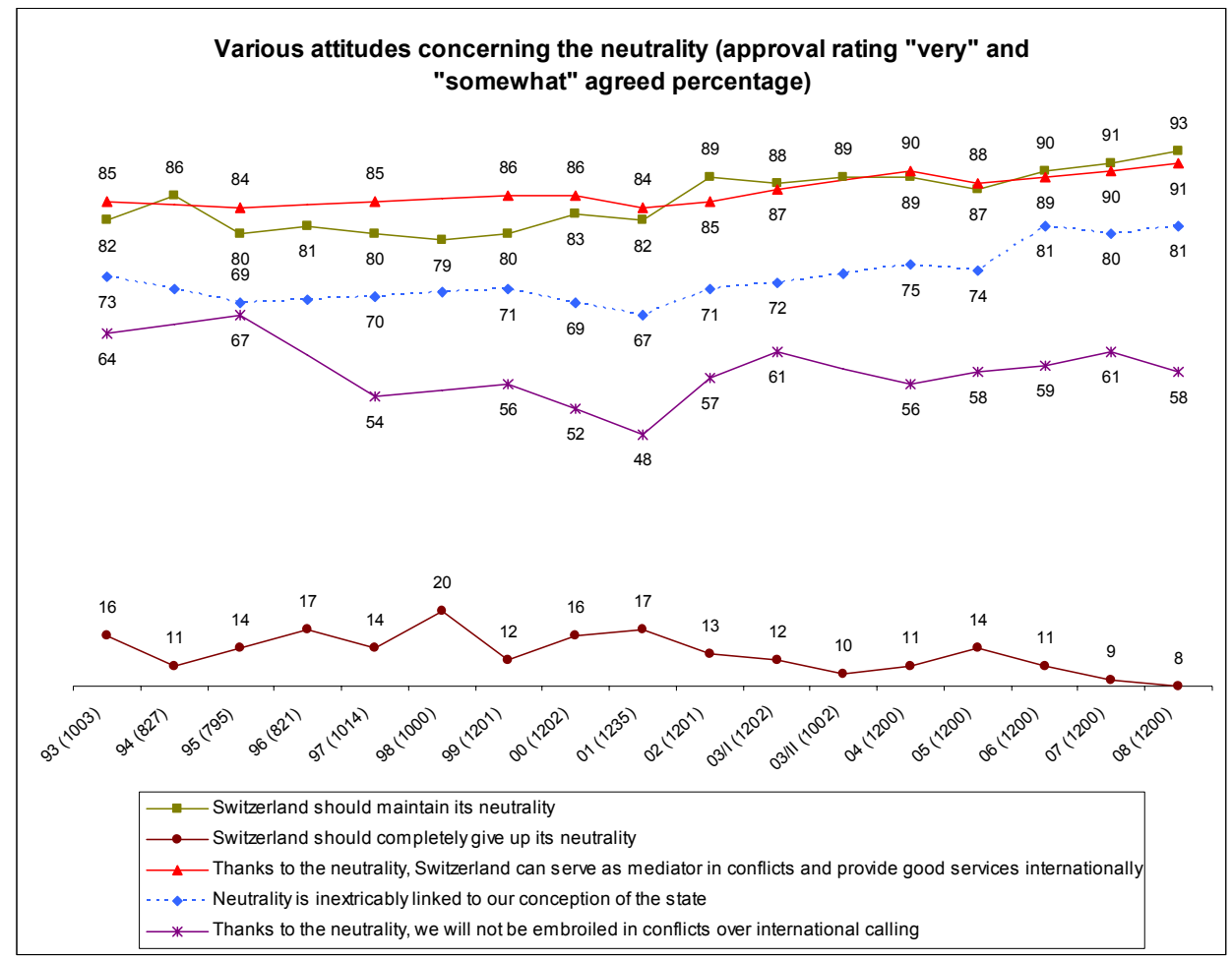

Figure 2: Swiss Public Opinion Regarding Neutrality (1993-2008).

(C) K. Haltiner Si/1031/08/sw)

an external mission creates a huge controversy among the political parties in Switzerland. The counter-intuitive coalition between the left-wing social democrats and the right-wing populist party impedes any majority that might emerge in favor of international military engagement. This alliance also prevents the Swiss Army from carrying out necessary reforms. The social democrats privilege civilian contributions, while the populist party prefers to see the role of the army limited to the defense of Swiss territory. Public opinion is not much more inclined to support military missions abroad.

With the rise of new security challenges, Swiss public opinion has become aware of the effects of globalization and the increasing level of interdependency in security policy. Today the distinction between war and peacekeeping is clearly understood. However, the Swiss cling to a traditional-i.e., Cold War-concept of peace promotion, one that relies almost exclusively on civilian means. As was previously discussed, this sector is well developed in Switzerland, and is well represented within the PfP and the EAPC. This concept is inherited from Switzerland's history of neutrality: "The tradition of the 'good offices' has favorably influenced domestic adhesion to extending ci- 


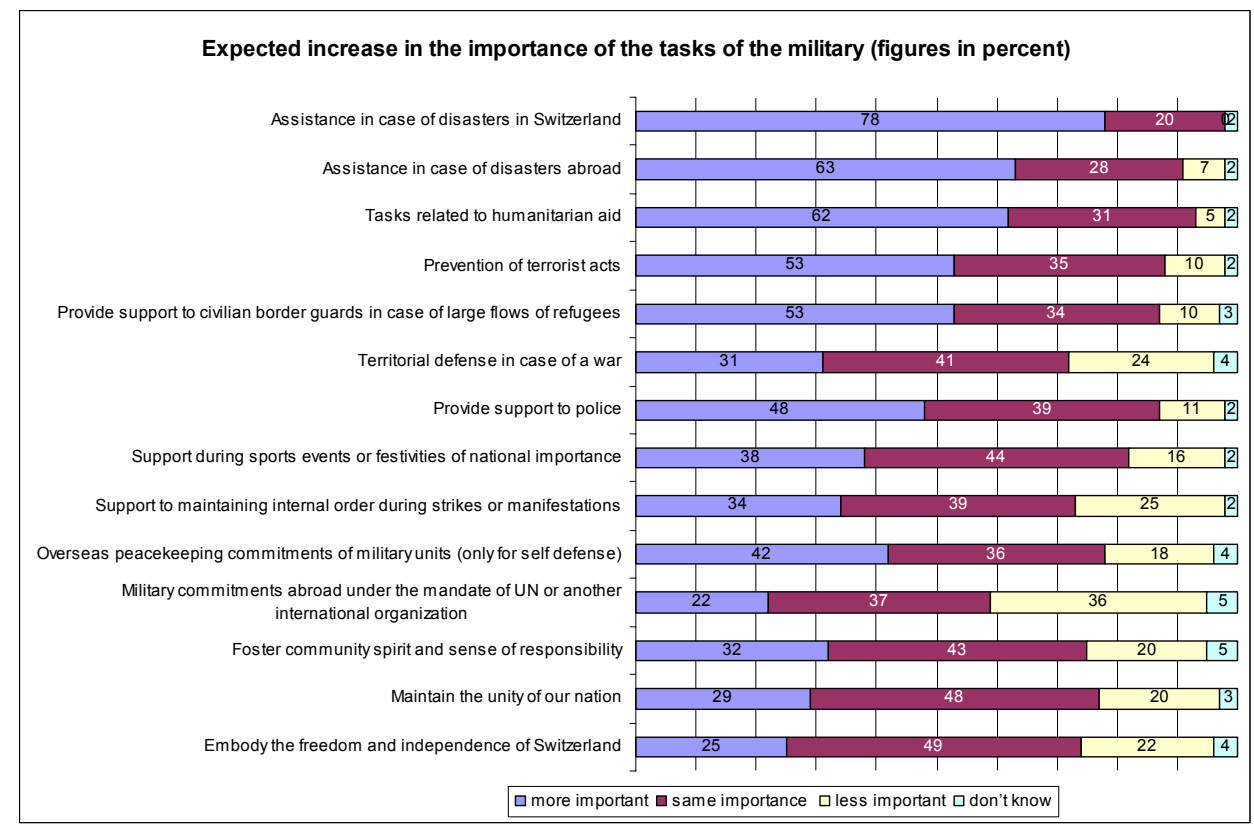

Figure 3: Expected Importance of Tasks of the Swiss Army.

(C) K.W. Haltiner Si/913/08/P9/sw)

vilian peace promotion policy." 22 Surveys show that this inclination is not on the wane. More than 90 percent of the Swiss population thinks that its policy of neutrality requires Switzerland to play a mediating role in conflicts. It is also striking that a significant majority of the population believe that neutrality will protect the country from being involved in international conflicts (see Figure 2). Although a small majority generally accepts the notion of international military engagement, opinions diverge much more on the question of sending armed troops. ${ }^{23}$ With regard to the role of the Swiss Army, a tendency indicates that a belief in its role purely as a guarantor of territorial defense is gradually losing importance. ${ }^{24}$ For the future, the Swiss public sees the na-

22 Translated by the author, from Daniel Trachsler, ed., "Promotion civile de la Paix: Potentiel et Limites," Politique de sécurité: analyses du CSS, No. 63 (Zürich: CSS ETH Zürich, November 2009); available at http://www.ssn.ethz.ch/Aktuell/CSS-Analysen/Detail/?lng=de\& id $=109198$.

23 Département fédéral de la défense, de la protection de la population et des sports - Politique de sécurité POLSEC, Les tendances de l'opinion suisse en matière de politique extérieure, de politique de sécurité et de défense, Principaux résultats (Zürich: ETH/VBS, 28 August 2008), 6; available at www.vbs.admin.ch/internet/vbs/fr/home/documentation/publication/ p_security.

24 Ibid., 6. 
tion playing an increasing role in humanitarian aid, both domestic or international, and peacekeeping, rather than becoming involved in international military operations (see Figure 3).

However, civilian engagement remains today the preferred instrument to achieve these ambitions, a sentiment that is reflected in the growing level of spending in that domain. ${ }^{25}$ On one hand, Switzerland's active engagement in civilian arenas compensates for the controversial rejection of involvement on the part of the Swiss Army. On the other hand, this emphasis on civilian engagement poses the risk of creating unrealistic expectations among the public and the political class about the benefits that a Swiss policy of peace promotion can generate on the international scene. But the situation also highlights the lack of coherence in the orientation toward foreign and security policy on the part of the concerned departments, which have divergent conceptions of Switzerland's appropriate role in promoting international peace. After considering the constraints, we will now turn to thinking about future perspectives in shaping Switzerland's security policy.

\section{Prospects for Swiss Civilian-Military International Engagement}

The Western Five have proved that neutrality or military non-alignment does not prevent proactive engagement with and solidarity in constructing European security and managing international challenges. With little objectivity, politicians and public opinion in Switzerland have poured cold water on this sensible logic. In an increasingly interdependent security context, however, understanding neutrality as an end in itself rather than as a means can only lead to isolation and loss of credibility. While committed to the principle of neutrality as an effective tool of maneuver in foreign policy, the Swiss government must pursue its involvement in a multilateral and institutionalized international security configuration. On the practical level, activities should be conducted under a "whole of government" approach, with coherent interdepartmental goals and involving military participation: "Civilian peace promotion must not become essentially an instrument compensating [for] the deficits recorded somewhere else in Swiss international positioning, and allowing a general exemption to [devolve] to fundamental questions regarding external and security policy." 26 The Swiss government increasingly acknowledges the importance of the complementary roles of civilian and military components in international crisis management: "International politics cannot be limited to dialogue and diplomacy. Its mission is also to seek international peace and security, if necessary by military or other constraining means... Switzerland must also face this challenge." 27

25 From 37.9 to 57 million Swiss Francs between 2000 and 2008, according to Daniel Trachsler, ed., "Promotion civile de la Paix: Potentiel et Limites," 2.

26 Translated by the author, from Daniel Trachsler, ed., "Promotion civile de la Paix: Potentiel et Limites," 4.

27 Translated by the author, from Der Schweizerische Bundesrat, Aussenpolitischer Bericht 2009, Bericht 09.052 (Bern: DFAE, 2 September 2009), 3; available at www.eda.admin.ch/ etc/medialib/downloads/edazen/doc/publi/aussen.Par.0001.File.tmp/AB09_de. 
The main question remains the participation of the Swiss Armed Forces in this effort. A fundamental debate should be undertaken to define the realistic threats facing Switzerland, followed by a delineation of the consequent missions and organization of the army in the future. We can assume that territorial defense is no longer pertinent in the new European and international security context. In that regard, we may also question the relevance of a militia-based army with a large conscription program. Furthermore, the association commonly made between this system and the notion of national identity rests on purely subjective analysis. At any rate, the militia system is no longer so popular in Switzerland anyway. One orientation should be the gradual professionalization of the Swiss military, and an effort to maximize flexibility in order to better face realistic threats. More importantly, such a transformation would contribute to clarifying the roles between the civilian, military, and (domestically) police components in the Swiss security architecture. This would provide the government with a flexible and complementary "whole of government" instrument, which would enhance the effectiveness and credibility of the Swiss position in international crisis management. While proving its solidarity with Euro-Atlantic multilateral security structures, Switzerland would achieve this objective by respecting its internal political and legal constraints - i.e., respect for neutrality, abstention from taking part in combat, and participation in UN- or OSCE-mandated missions. Unlike the four EU non-aligned members, Switzerland is not challenged by the CSDP solidarity clause, which contradicts the principle of non-alignment.

In a context of weak political support for military involvement in peace promotion efforts, the internal components of the Swiss Army also have difficulty in giving up their conservative approach to their perception of the security environment. Ensuring transparency and objectivity vis-à-vis the population and gradually convincing it of the domestic benefits from allowing the military to play an international role would guarantee the Swiss Army's legitimacy in the long term. More active participation in PfP activities is one solution that might help move Swiss public opinion in this direction.

\section{Prospects for Swiss Participation in NATO Operations}

The PfP certainly represents one of the best opportunities for Switzerland to legitimize the raison d'etre of its army, since it ensures the principles of diversity and self-differentiation, which is fully compatible with Swiss domestic obligations. It is therefore in Switzerland's interest not only to maintain but also to develop civilian-military contributions within the PfP framework. Considering the constraints on Switzerland's military capacities, the most likely manner for this participation to unfold going forward is through the option of participating in niche operations. In the Balkans, the Swiss Army has been proving itself to be a "high value asset" ${ }^{28}$ in air transport. Work in this sector can be extended. Other valuable contributions - in such areas as ceasefire control, land mine clearance, and expertise in arms elimination - would gain visibility if they were further developed. Flexible capacities may also represent an advantage to intervene in different phases of crisis management (peacekeeping, peace-building, etc.). These con-

${ }^{28}$ Daniel Möckli, ed., "Auslandeinsätze der Armee: Stand und Optionen,” 3. 


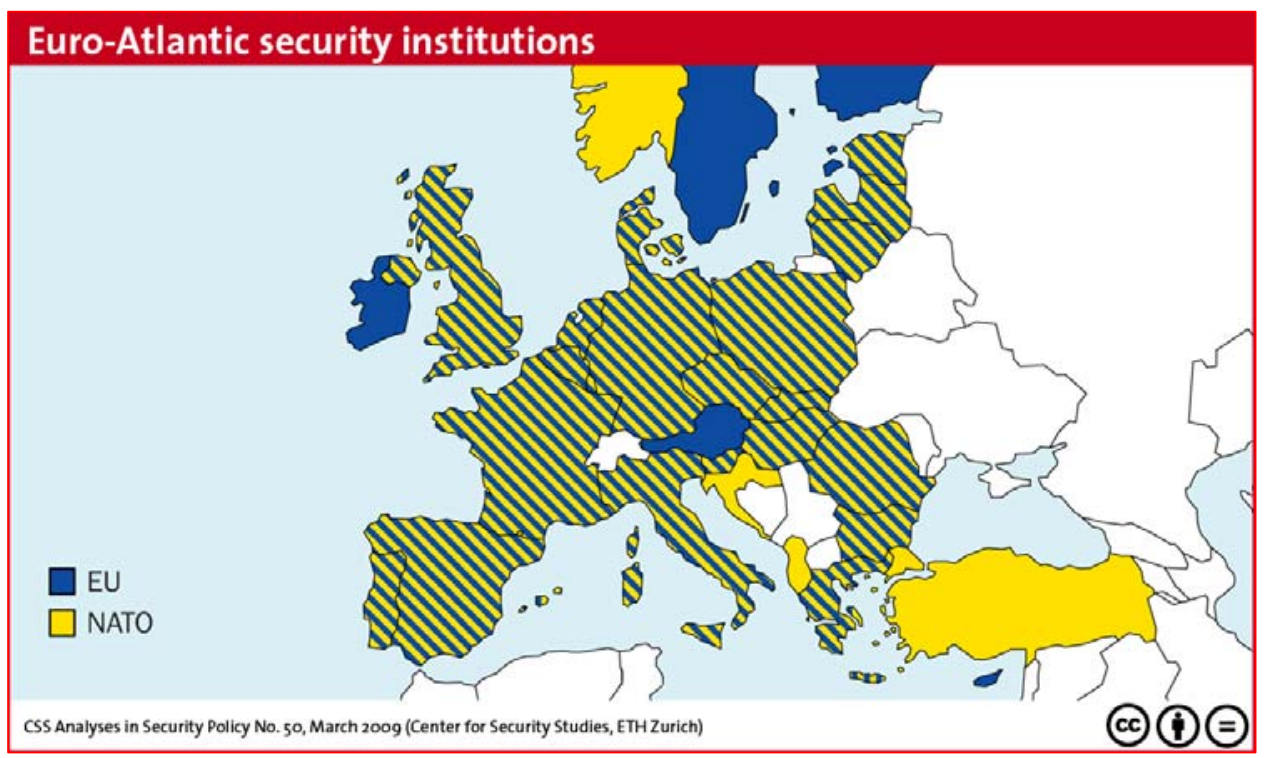

Figure 4: The Euro-Atlantic Security Architecture.

tributions can be optimized if they are complemented by adequate efforts in the area of civilian peace promotion, which relies, as was discussed above, on highly specialized expertise. Domestically, these contributions can be justified in the sense that they represent the only possibility for the Swiss Armed Forces to receive training and test their capabilities under real conditions. This is the argument adopted by the German government, which is for obvious historical reasons generally reluctant to deploy troops abroad. The Swiss experience within KFOR has indeed demonstrated the value of the opportunity to test interoperability and capacities in international crisis management.

In the medium term, NATO's major focus will remain on military operations. Whatever the output of the new Strategic Concept will bring, particularly with regard to partnerships, it is certain that the partners states' merit will be increasingly assessed according to their concrete participation in the field. The added value of the PfP depends as well on the importance that the partner countries attach to it. It is in Switzerland's interest, for external and domestic purposes, to show its commitment to the Partnership and its willingness to enhance its engagement with the Euro-Atlantic security community.

\section{Conclusion}

In Switzerland, the concept neutrality virtually always enters into discussions about foreign and security policy, but rarely creates a deep debate. Surveys show that abandoning neutrality will not be a possibility in Switzerland in the near future; a similar state of opinion exists with regard membership in the EU. NATO membership also re- 
mains out of the question. But participation in the PfP holds the advantage of placing more comprehensible limits on cooperation. This may explain why public opinion is less reluctant about cooperating with NATO than with the EU. So far, Switzerland has no institutionalized link with the EU's Common Defense and Security Policy (CDSP) or the Common Foreign and Security Policy (CFSP), and the Western Five are increasingly becoming a " $4+1$ " formula (see Figure 4). More than unique, the Swiss position is becoming increasingly odd and isolated in the European security arena. And it will remain so, should subjective views of Switzerland's interests keep confusing the means and ends of neutrality. Ultimately, however, the small, neutral state will have to come around: "when it comes to solidarity, even Switzerland is tied to EU-Europe: when Europe is threatened, Switzerland is threatened too." ${ }^{29}$

Even within the framework of the PfP, it is going to be more difficult for nonaligned states like Switzerland to maintain privileged relationships with the member states of NATO. Indeed, even if NATO relies more and more on its partnerships, the challenge will be to protect the particularities that have enabled the PfP to become a successful platform of exchange and participation in collective security. If Western non-aligned countries must show themselves to be particularly proactive in using this instrument, their request addressed to the Alliance for more consultation and transparency will be perfectly understandable, and must be taken into consideration. In addition, this would enhance NATO's legitimacy, as well as the partner states' sense of ownership. This is possible if NATO's missions are clearly defined in today's variable security environment. NATO should keep this in mind while working on the new Strategic Concept; a similar comprehensible vision must be proposed to the partner states. In that way, the Allies would ensure the commitment of Partners like Switzerland that are hesitant to engage with them. And it would help prove that small-and neutralstates can play a role in building international security.

29 Hanna Ojanen, ed., "Neutrality and Non-alignment in Europe Today," FIIA Report, No. 6 (Helsinki: Finnish Institute of International Affairs, September 2003), 67; available at www.upi-fiia.fi/en/publication/55/. 


\section{Bibliography}

Aussenpolitischer Bericht 2009. Bern: DFAE, 2009.

Bericht des Bundesrates an die Bundesversammlung über die Sicherheit der Schweiz. Bern: Schweizerische Bundesrat, 2010.

Bundesverfassung der Schweizerischen Eidgenossenschaft. Bern: Die Bundesbehörden der Schweizerischen Eidgenossenschaft, 1998.

de Dardel, Jean-Jacques. Whither the Euro-Atlantic Partnership? Partnership and NATO's New Strategic Concept In GCSP Geneva Papers. Vol. 10. Geneva: Geneva Centre for Security Policy, 2009.

For a Euro-Atlantic Partnership (EAP) Looking to the Future: Proposals for NATO's New Strategic Concept. Government of Austria, Ireland and Switzerland, 2009.

Götschel, Laurent. Small States Inside and Outside the European Union: Interests and Policies. Boston, MA: Kluwer Academic Publishers, 1998.

Individual Partnership Program between Switzerland and NATO for 2010, NATO/EAPC/PfP Unclassified Switzerland only. Bern: Directorate for Security Policy (DSP), 2009.

Jahresbericht 2009 des Bundesrates über die Teilnahme der Schweiz am EuroAtlantischen Partnerschaftsrat und an der Partnerschaft für den Frieden. Bern: Eidgenössisches Departement für Verteidigung, Bevölkerungsschutz, und Sport, Generalsekre-tariat Sicherheitspolitik SIPOL, 2010.

L'Essentiel sur la neutralité suisse. Bern: DFAE, 2005.

Les tendances de l'opinion suisse en matière de politique extérieure, de politique de sécurité et de défense, Principaux résultats. Zürich: ETH/VBS, 2008.

Möckli, Daniel. Auslandeinsätze der Armee: Stand und Optionen In CSS Analysen zur Sicherheitspolitik. Vol. 67. Zürich: CSS ETH Zürich, 2010.

Ojanen, Hanna. Neutrality and Non-alignment in Europe Today In FIIA Report. Helsinki: Finnish Institute of International Affairs, 2003.

Pond, Susan. "Understanding the PfP Tool Kit." NATO Review (2004).

Rapport sur la neutralité publié en annexe du Rapport sur la politique extérieure de la Suisse dans les années 90. Bern: Département fédéral des affaires étrangères (DFAE), 1993.

The Hague Conventions and Declarations. The Hague, 1907.

Trachsler, Daniel. Promotion civile de la Paix: Potentiel et Limites In Politique de sécurité: analyses du CSS. Zürich: CSS ETH Zürich, 2009.

UN Charter. New York: United Nations, 1945. 